This is an open access article distributed under the terms of the Creative Commons BY-NC-ND Licence

\title{
OsCaM1-1 overexpression in the transgenic rice mitigated salt-induced oxidative damage
}

\author{
T. KAEWNERAMIT, T. BUABOOCHA, P. SANGCHAI, and N. WUTIPRADITKUL* \\ Department of Biochemistry, Faculty of Science, Chulalongkorn University, Patumwan, Bangkok 10330, Thailand
}

\begin{abstract}
Various physiological and biochemical parameters associated with improved salinity tolerance in the transgenic rice lines overexpressing OsCaM1-1 gene and wild-type KDML105 were compared $3 \mathrm{~d}$ after exposure to $150 \mathrm{mM} \mathrm{NaCl}$. The results showed higher relative water content, relative growth rate, content of photosynthetic pigments (chlorophylls $a, b$, and carotenoids), DPPH scavenging activity, and activities of superoxide dismutase, catalase, ascorbate peroxidase, and glutathione reductase in the transgenic plants when compared with the wild-type and control, KDML105 transformed with blank vector, whereas $\mathrm{H}_{2} \mathrm{O}_{2}$ content, $\mathrm{Na} / \mathrm{K}$ and $\mathrm{Na} / \mathrm{Ca}$ ratio, lipid peroxidation, and electrolytic leakage were lower. Taken together, the OsCaM1-1 gene overexpression probably reduced salt-induced oxidative damage in the transgenic plants by enhancing the activities of antioxidant enzymes.
\end{abstract}

Additional key words: antioxidant activity, calmodulin, carotenoids, chlorophyll, $\mathrm{NaCl}$, reactive oxygen species.

\section{Introduction}

Various abiotic stresses such as salinity, drought, or extreme temperatures adversely affect growth, development, and the yield of crop plants. Exposure of plants to these stresses may provoke osmotic stress, oxidative stress, and protein denaturation. Simultaneously, plants defend themselves by accumulation of compatible solutes, stress proteins, and antioxidants (Zhu 2002, Apel and Hirt 2004). Reactive oxygen species (ROS) can cause damage to DNA and almost every organic constituent of the living cell (Fridovich 1986, Davies 1987, Imlay and Linn 1988). Thus, a highly efficient antioxidant system is present in all plants to detoxify ROS. Plants have developed a series of enzymatic and non-enzymatic antioxidants (Sairam and Tyagi 2004, Khan et al. 2012, 2014, Per et al. 2017). Major ROS scavenging enzymes include superoxide dismutase (SOD: EC 1.15.1.1), ascorbate peroxidase (APX: EC 1.11.1.11), catalase (CAT: EC 1.11.1.6),

glutathione reductase (GR: EC 1.8.1.7) and nonenzymatic antioxidants include ascorbic acid and glutathione.

Eukaryotes utilize changes in the cytosolic $\mathrm{Ca}^{2+}$ as a second messenger to generate cellular responses to a wide variety of extracellular stimuli including abiotic and biotic stresses and also plant hormones, e.g., abscisic acid (ABA). The $\mathrm{Ca}^{2+}$ transmits the stress signal downstream by several $\mathrm{Ca}^{2+}$ sensors or $\mathrm{Ca}^{2+}$-binding proteins such as calmodulin (CaM), calcium-dependent protein kinases (CDPK), and calcineurin B-like proteins (CBLs), which can regulate intracellular physiological responses (Yang and Poovaiah 2002, Bouche et al. 2005). The CaM is a primary calcium sensor in all eukaryotes. It binds calcium and regulates the activity of a wide range of effector proteins in response to calcium signals. Cam genes families have been identified in several plants including rice which has five OsCam genes. OsCam1-1, OsCam1-2,

Submitted 10 May 2018, last revision, 26 September 2018, accepted 3 October 2018.

Abbreviations: APX - ascorbate peroxidase; CaM - calmodulin; CAT - catalase; GR - glutathione reductase; KDML105 - Khao Dawk Ma Li 105; MDA - malondialdehyde; ROS - reactive oxygen species; RWC - relative water content; SOD - superoxide dismutase.

Acknowledgments: This study was supported by the Chulalongkorn University: the research group "Special Task Force for Activating Research (STAR): Biochemical and Molecular Mechanisms of Rice in Changing Environments" by Ratchadaphisek-sompot Endowment Fund, the Asia Research Center (ARC), and a scholarship to develop research potential for the Department of Biochemistry, Faculty of Science, Chulalongkorn University. We thank Dr. Vandna Rai, ICAR-National Research Centre on Plant Biotechnology, for useful comments and English proofreading.

* Corresponding author; e-mail: nuchanat.w@chula.ac.th 
and OsCam1-3 encode identical protein, OsCaM1, whereas $O s C a m 2$ and $O s C a m 3$ encode a protein with only two amino acid differences from typical $\mathrm{CaM}$, and share $98.7 \%$ amino acid sequence identity with OsCaM1 (Phean-O-Pas et al. 2005, Booburapong and Buaboocha 2007). OsCaM1-1 encodes a functional $\mathrm{Ca}^{2+}$-binding $\mathrm{CaM}$ and is highly expressed in vascular tissues and the emerged lateral roots (Phean-O-Pas et al. 2008). The expression of OsCaM1-1 was induced under osmotic stress and salt stress (Chinpongpanich et al. 2012). In addition, the transgenic rice plants overexpressing

\section{Materials and methods}

Growth conditions and treatments: Seeds of Oryza sativa L. var. indica cv. Khao Dawk Ma Li 105 (KDML105) were obtained from Department of Agriculture, Ministry of Agriculture and Cooperatives, Bangkok, Thailand. The transgenic rice plants containing OsCaM1-1 gene under the control of 35SCaMV promoter (35SCaMV-OsCaM1-1) were previously constructed by Agrobacterium-mediated transformation via pCAMBIA1301 plasmid (Saeng-ngam et al. 2012).

Seeds of three transgenic rice plants overexpressing OsCaM1-1, the transgenic line harboring the T-DNA from pCAMBIA1301 alone as the negative control, and wild-type KDML105 were dehusked and sterilized with $70 \%(\mathrm{v} / \mathrm{v})$ ethanol for $2 \mathrm{~min}$ and then with $5 \%(\mathrm{~m} / \mathrm{v})$ sodium hypochlorite for $20 \mathrm{~min}$. The seeds were rinsed three times with sterile water and germinated in a nutrient broth medium (NB) (Li et al. 1993) containing $0.8 \%$ $(\mathrm{m} / \mathrm{v})$ agar at a temperature of $25-28{ }^{\circ} \mathrm{C}$, a 16 -h photoperiod, and an irradiance of $200 \mu \mathrm{mol} \mathrm{m} \mathrm{m}^{-2} \mathrm{~s}^{-1}$. After $7 \mathrm{~d}$, germinated seeds were transferred to a Limpinuntana's nutrient solution (Wutipraditkul 2015) and grown under the previously mentioned conditions for $14 \mathrm{~d}$. Threeweek-old seedlings were exposed to a nutrient solution supplemented with $0,50,100$, or $150 \mathrm{mM} \mathrm{NaCl}$ for $3 \mathrm{~d}$. After $3 \mathrm{~d}$ of the salt stress, the leaves were harvested and were randomly selected and oven-dried at $60{ }^{\circ} \mathrm{C}$ for $72 \mathrm{~h}$ for determination of dry mass. Relative growth rate (RGR) was determined following the method of Beadle (1993) and it was calculated from the increase in dry mass from the beginning to the end of $\mathrm{NaCl}$ treatment using an equation: $R G R=\left(\operatorname{lnM}_{\mathrm{f}}-\ln \mathrm{M}_{\mathrm{i}}\right) /\left(\mathrm{t}_{\mathrm{f}}-\mathrm{t}_{\mathrm{i}}\right)$, where $\mathrm{M}$ is the shoot or root dry mass, $t$ is the time and subscripts denote the initial (day 0) and final samplings (day 3 ).

Content of $\mathrm{Na}^{+}, \mathrm{K}^{+}$, and $\mathrm{Ca}^{2+}$ : Leaves (0.02 g) were dried in an electric oven at $60{ }^{\circ} \mathrm{C}$ for $3 \mathrm{~d}$. Dry samples were homogenized in $0.5 \mathrm{M} \mathrm{HNO}_{3}(65 \%, \mathrm{v} / \mathrm{v})$ and rested in normal condition for $2 \mathrm{~d}$. Then, the sample was incubated at $80{ }^{\circ} \mathrm{C}$ for $1 \mathrm{~h}$ in an electric oven. The content of $\mathrm{Na}^{+}, \mathrm{K}^{+}$, and $\mathrm{Ca}^{2+}$ was measured by atomic absorption spectrophotometer (AA280FS, Agilent Technologies, USA) according to the method of Munns et al. (2010).
OsCam 1-1 exhibited increased ABA biosynthesis and better resistance to salinity than the control plants (Saengngam et al. 2012). Chaicherdsakul et al. (2017) also suggested a possible CaM-regulated salinity tolerance mechanism via redox signaling and homeostasis. Taken together, OsCam 1-1 may contribute to salt resistance in rice. Therefore, we investigated antioxidant systems and other physiological changes in the transgenic plants overexpressing OsCam1-1 induced by salt stress and compared them with those in the wild-type and control transgenic lines without $O s C a m 1-1$ overexpression.

$\mathrm{H}_{2} \mathrm{O}_{2}$ content was measured by the modified method of Jana and Choudhuri (1981). $\mathrm{H}_{2} \mathrm{O}_{2}$ was extracted by homogenizing $100 \mathrm{mg}$ leaf tissue with liquid nitrogen followed by grinding in $3 \mathrm{~cm}^{3}$ of $50 \mathrm{mM}$ phosphate buffer ( $\mathrm{pH} 7)$. The homogenate was filtered and centrifuged $\left(6000 \mathrm{~g}, 4{ }^{\circ} \mathrm{C}, 25 \mathrm{~min}\right)$, and $0.9 \mathrm{~cm}^{3}$ of the supernatant was mixed with $0.3 \mathrm{~cm}^{3}$ of $1 \%(\mathrm{v} / \mathrm{v}) \mathrm{TiCl}_{4}$ in conc. $\mathrm{HCl}$ and centrifuged $\left(6000 \mathrm{~g}, 4^{\circ} \mathrm{C}, 15 \mathrm{~min}\right)$. The absorbance of the yellow supernatant was measured at $410 \mathrm{~nm} . \mathrm{H}_{2} \mathrm{O}_{2}$ content was then calculated according to a standard curve drawn using different known concentrations of $\mathrm{H}_{2} \mathrm{O}_{2}$.

MDA content: Lipid peroxidation was estimated by measuring the formation of malondialdehyde (MDA), a breakdown product of lipid peroxidation, according to De Vos et al. (1989). Leaves $(0.1 \mathrm{~g})$ were ground to fine powder by mixer mill (MM400, Retsch, Germany) at a frequency of $35 \mathrm{~Hz}$ per min twice. Then, $1 \mathrm{~cm}^{3}$ of $0.1 \%$ trichloroacetic acid (TCA) was added and the mixture was centrifuged $\left(5000 \mathrm{~g}, 25^{\circ} \mathrm{C}, 15 \mathrm{~min}\right)$. After centrifugation, $0.3 \mathrm{~cm}^{3}$ of the supernatant was mixed with $0.75 \mathrm{~cm}^{3}$ of $0.25 \%$ 2-thiobarbituric acid (TBA) in $10 \%$ TCA. The absorbance of resulting supernatant was taken at 532 and $600 \mathrm{~nm}$. MDA content was determined by subtracting absorbance of supernatant at $600 \mathrm{~nm}$ from that of $532 \mathrm{~nm}$ using absorbance coefficient of $155 \mathrm{mM}^{-1} \mathrm{~cm}^{-1}$.

Membrane permeability (electrolytic leakage): Leaves were harvested $3 \mathrm{~d}$ after salt stress imposition and cut into $1-\mathrm{cm}$ segments. Leaf segments were placed into $5 \mathrm{~cm}^{3}$ of deionized water in a test tube to remove solutes from leaf surfaces. Then the sample was submerged in $5 \mathrm{~cm}^{3}$ of deionized water in test tube for $2 \mathrm{~h}$ and electrical conductivity (EC) was measured before and after autoclaving at $121{ }^{\circ} \mathrm{C}$ for $20 \mathrm{~min}$. The cell membrane stability [\%] was calculated as $100-\left[\left(\mathrm{EC}_{1} / \mathrm{EC}_{2}\right) \times 100\right]$, where $\mathrm{EC}_{1}$ is electrical conductivity after dipped in deionized water for $2 \mathrm{~h}$ and $\mathrm{EC}_{2}$ is electrical conductivity after autoclaved for $20 \mathrm{~min}$ (Blum and Ebercon 1981). 
Relative water content: Plants from each treatment were randomly selected and the method described by Barrs and Whetherley (1962) was followed. About $0.1 \mathrm{~g}$ leaf sample was cut into smaller pieces and weighed to determine initial mass $\left(\mathrm{M}_{\mathrm{i}}\right)$. The leaf samples were then floated in freshly de-ionized water for $12 \mathrm{~h}$ and weighed thereafter to determine fully water saturated mass $\left(\mathrm{M}_{\mathrm{f}}\right)$. The sample was oven-dried at $60{ }^{\circ} \mathrm{C}$ for $3 \mathrm{~d}$ and the dry mass was obtained $\left(\mathrm{M}_{\mathrm{d}}\right)$. The RWC [\%] was determined as $\left[\left(M_{i}-M_{d}\right) /\left(M_{f}-M_{d}\right)\right] \times 100$.

Photosynthetic pigments: Chlorophylls and carotenoids were extracted in $2 \mathrm{~cm}^{3} \mathrm{~N}, \mathrm{~N}$-dimethyl formamide (DMF) by grinding $0.05 \mathrm{~g}$ of rice leaves in mixer mill MM400 at a frequency of $35 \mathrm{~Hz}$ per min twice. The homogenate was centrifuged $\left(15000 \mathrm{~g}, 10 \mathrm{~min}, 4^{\circ} \mathrm{C}\right)$ and the absorbance of the resulting supernatant was taken at 461, 625, and $664 \mathrm{~nm}$. Total chlorophyll and carotenoid content was calculated according to modified method of Arnon (1949).

DPPH radical scavenging activity: Leaves $(0.1 \mathrm{~g})$ were ground to fine powder by mixer mill MM400. Then, $1.0 \mathrm{~cm}^{3}$ of absolute methanol was added and evaporated by Centrivap (Labconco, Canada) concentrator. The samples were reacted with the 1,1-diphenyl-2-picrylhydrazyl (DPPH) in an ethanol solution by mixing $0.5 \mathrm{~cm}^{3}$ of sample, $3 \mathrm{~cm}^{3}$ of absolute ethanol, and $0.3 \mathrm{~cm}^{3}$ of $0.5 \mathrm{mM}$ DPPH radical solution in ethanol. The change in colour (from deep violet to light yellow) was read at
$517 \mathrm{~nm}$ after $30 \mathrm{~min}$ of reaction. The mixture of ethanol and sample (without DPPH radical solution) served as blank. The control solution was prepared by mixing ethanol and DPPH radical solution. The scavenging activity percentage AA [\%] was calculated as $\left[\left(\mathrm{A}_{\text {control }}\right.\right.$ $\left.\left.\mathrm{A}_{\text {sample }}\right) / \mathrm{A}_{\text {control }}\right] \times 100$ according to Brand-Williams et al. (1995).

Enzyme extractions and assay: Enzyme extracts for evaluating SOD, CAT, APX, and GR activities were prepared by freezing leaf samples $(0.5 \mathrm{~g})$ in liquid nitrogen followed by grinding with $5 \mathrm{~cm}^{3}$ of cold extraction buffer $[0.1 \mathrm{M}$ phosphate buffer $(\mathrm{pH}$ 7.5) containing $0.5 \mathrm{mM}$ ethylenediaminetetraacetic acid (EDTA) and $5 \mathrm{mM}$ dithiothreitol], except that in the case of APX activity, $5 \mathrm{mM}$ ascorbic acid was added to the extraction buffer. Homogenates were filtered and centrifuged (15 $\left.000 \mathrm{~g}, 4{ }^{\circ} \mathrm{C}, 20 \mathrm{~min}\right)$ prior to harvesting the supernatant as the enzyme extract. Activities of SOD, CAT, APX, and GR were assayed as described previously (Wutipraditkul et al. 2015).

Protein content in the enzyme extract was measured according to the method of Bradford (1976) using bovine serum albumin as standard.

Statistical analysis: All analyses were completely randomized with five to ten replicates per treatment. Statistical analysis was performed using one-way ANOVA and differences between the mean values were compared using Duncan's test at $P<0.05$.

\section{Results and discussion}

The $\mathrm{Na}^{+}$content in leaves of all the three independent transgenic lines overexpressing OsCaM1-1, the control transgenic rice line (with T-DNA from pCAMBIA1301), and wild-type (WT) plants significantly increased after subjecting them to $150 \mathrm{mM} \mathrm{NaCl}$ stress for $3 \mathrm{~d}$. However, no significant difference of $\mathrm{K}^{+}$content was observed, while $\mathrm{Ca}^{2+}$ content of the control and WT decreased significantly. It is widely known that $\mathrm{K}^{+}$is required for maintaining the osmotic balance, affects opening and closing of stomata, and it is also an essential cofactor for many enzymes (Mahajan and Tuteja 2005). The $\mathrm{Ca}^{2+}$, which is an important determinant for plant salt tolerance, confers protective effects on plants under abiotic stress, plays an essential role for maintaining the structural and functional integrity of the plant cell membranes, regulates ion transport (Hadi and Karimi 2012) and acts as a second messenger in stress signaling. In this study, the increase of $\mathrm{Na} / \mathrm{K}$ and $\mathrm{Na} / \mathrm{Ca}$ ratios under salinity in leaves of the control and WT were significantly higher than in the three transgenic lines (Fig. 1 $A, B$ ). It has been known that due to high content of $\mathrm{Na}^{+}$, which is toxic to cell metabolism, ROS are produced and causes deleterious

effect on the functions of some enzymes (Niu et al. 1995). There are reports showing that $\mathrm{Na}^{+}$in plant compete with $\mathrm{Ca}^{2+}$ by entering the cell through channels resulting in increased $\mathrm{Na} / \mathrm{Ca}$ ratio under salinity (Hasegawa et al. 2000), which is consistent with our study. Similar to the transgenic rice, salt tolerant genotypes of Aloe vera maintained significantly lower $\mathrm{Na} / \mathrm{Ca}$ ratio and suffered less membrane damage (Jin et al. 2007).

The $\mathrm{H}_{2} \mathrm{O}_{2}$ contents in the leaves of all three transgenic lines, control and WT increased and reached its maximum after $3 \mathrm{~d}$ (data not shown). $\mathrm{H}_{2} \mathrm{O}_{2}$ content in all the plants increased in a concentration-dependent manner and reached its maximum at $150 \mathrm{mM} \mathrm{NaCl}$ but it reduced rapidly at $200 \mathrm{mM} \mathrm{NaCl}$ (data not shown). These results indicated that exposure time and $\mathrm{NaCl}$ concentration were important factors that affected rice oxidative stress. All parameters in subsequent experiments were examined after 3-d exposure to $150 \mathrm{mM} \mathrm{NaCl}$. The $\mathrm{H}_{2} \mathrm{O}_{2}$ content in all the transgenic lines was lower than that of the control and WT (Fig. 1C). The damage to cellular membranes due to lipid peroxidation can be indicated by the 
accumulation of the MDA. Here, MDA content was increased under $150 \mathrm{mM} \mathrm{NaCl}$ in all the plants (Fig. 1D), which is consistent with the previous reports in cotton and tobacco (Meloni et al. 2003, Savouré et al. 1999). However, the increase of MDA was less pronounced in the transgenic plants as compared with the control and WT. In many reports, production of ROS increases under salt stress (Hasegawa et al. 2000) and ROS-mediated membrane damage was a major cause of the $\mathrm{NaCl}$ toxicity in different plants such as rice, tomato, citrus, and cotton (Gueta-Dahan et al. 1997, Dionisio-Sese and Tobita 1998, Mittova et al. 2004, Ahmad et al. 2009, Pérez-Clemente et al. 2012). Salt stress induced ion leakage, indicating injury to membranes, which could be affected by ROS enhancing membrane lipid oxidation (Lechno et al. 1997, Savouré et al. 1999). The degree of cell membrane injury can be easily estimated by measurements of electrolytic leakage from the cells. Cell membranes are one of the first targets of many plant stresses and there are many reports showing that ion removal from leaf samples under abiotic stresses is higher than under normal conditions, e.g., in durum wheat under water stress, coffee under chilling stress, and NTHK1transgenic Arabidopsis under salinity (Bajji et al. 2001, Campos et al. 2003, Cao et al. 2007). Our results revealed a significant increase in electrolyte leakage in the control and WT plants (but not in the transgenic plants) (Fig. 1E), which correlated with lipid peroxidation (Fig. 1D). These results suggested that the overexpression of $O s C a M 1-1$ protected membrane to oxidative stress. It was observed that growth and adaptation of all transgenic lines were better than that of the control and WT. Consequently, the control and WT seedlings wilted and leaves turned yellow under salinity while the transgenic plants showed less wilting (Fig. 1 Suppl.).

RWC in the leaves of all the plants grown under salinity stress decreased significantly when compared to normal conditions (Fig. $2 A$ ). The reduction of RWC in stressed plants may be associated with a decrease in plant vigor, which was observed in many plant species such as

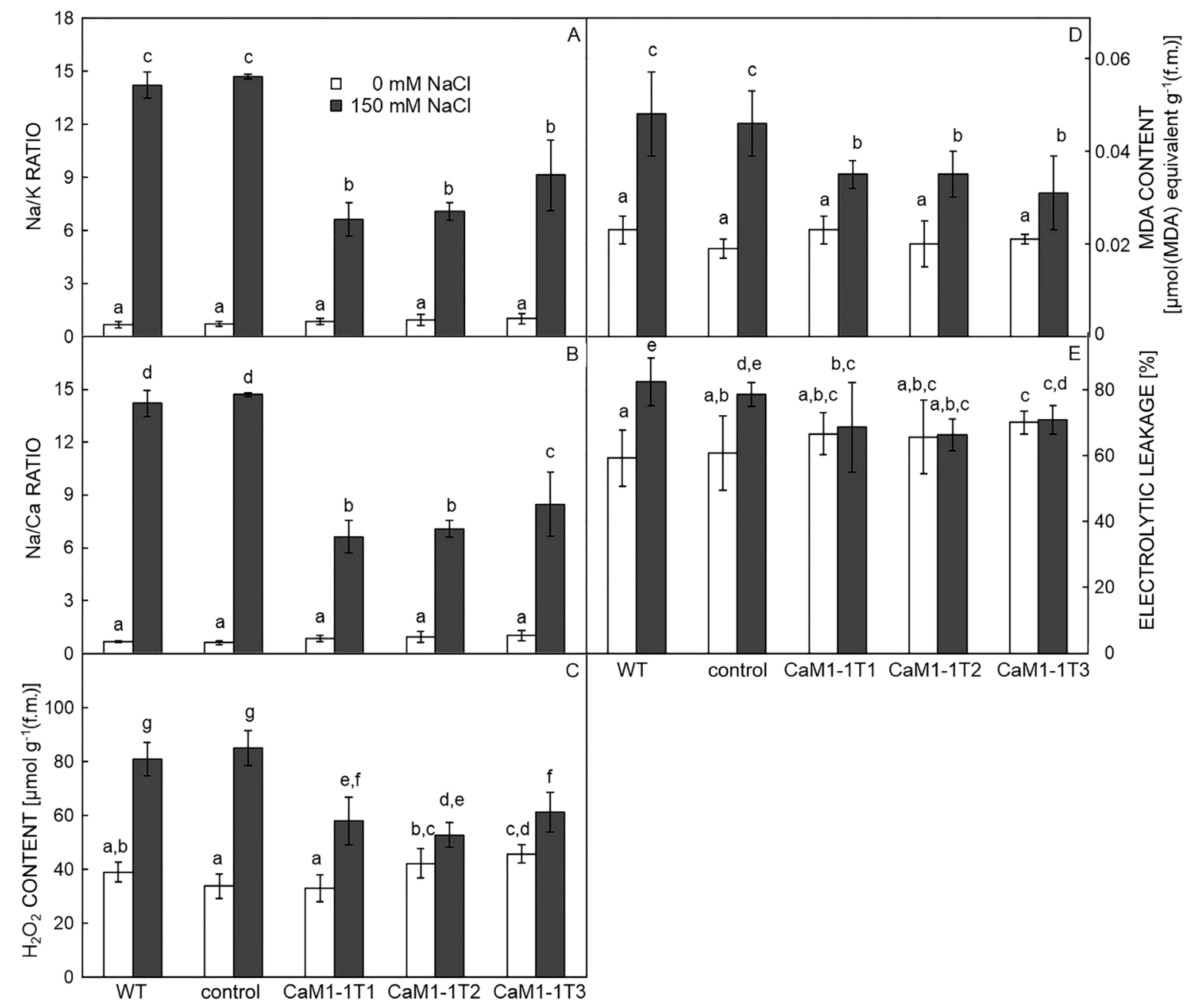

Fig. 1. Effect of $150 \mathrm{mM} \mathrm{NaCl}$ for $3 \mathrm{~d}$ on $\mathrm{Na} / \mathrm{K}$ ratio $(A), \mathrm{Na} / \mathrm{Ca}$ ratio $(B), \mathrm{H}_{2} \mathrm{O}_{2}$ content $(C)$, MDA content $(D)$, and electrolyte leakage $(E)$ of the transgenic rice plants overexpressing $O s C a M 1-1$ gene (CaM1-1T1, 2, and 3), the negative control transgenic line, and the wild-type. Means \pm SEs, $n=5$. Different letters indicate significant differences at $P<0.05$. 
rice, kidney bean, and maize or may result from the damage of cell membranes (Halder and Burrage 2003, Lopez et al. 2002, Valentovič et al. 2006). The higher reduction of RWC in the control and WT plants than the transgenic plants suggested that the overexpression of OsCaM1-1 helps the plants to maintain their ability for preserving more water in tissues. The relative growth rate
(RGR) of shoots (Fig. 2B) and roots (Fig. 2C) in the control and WT was reduced significantly but the RGR of shoots in the transgenic plants decreased only slightly. Consequently, the transgenic plants could recover and grow faster than the control and WT under salt stress condition (Fig. 1 Suppl.).

Our results also showed that salinity had no

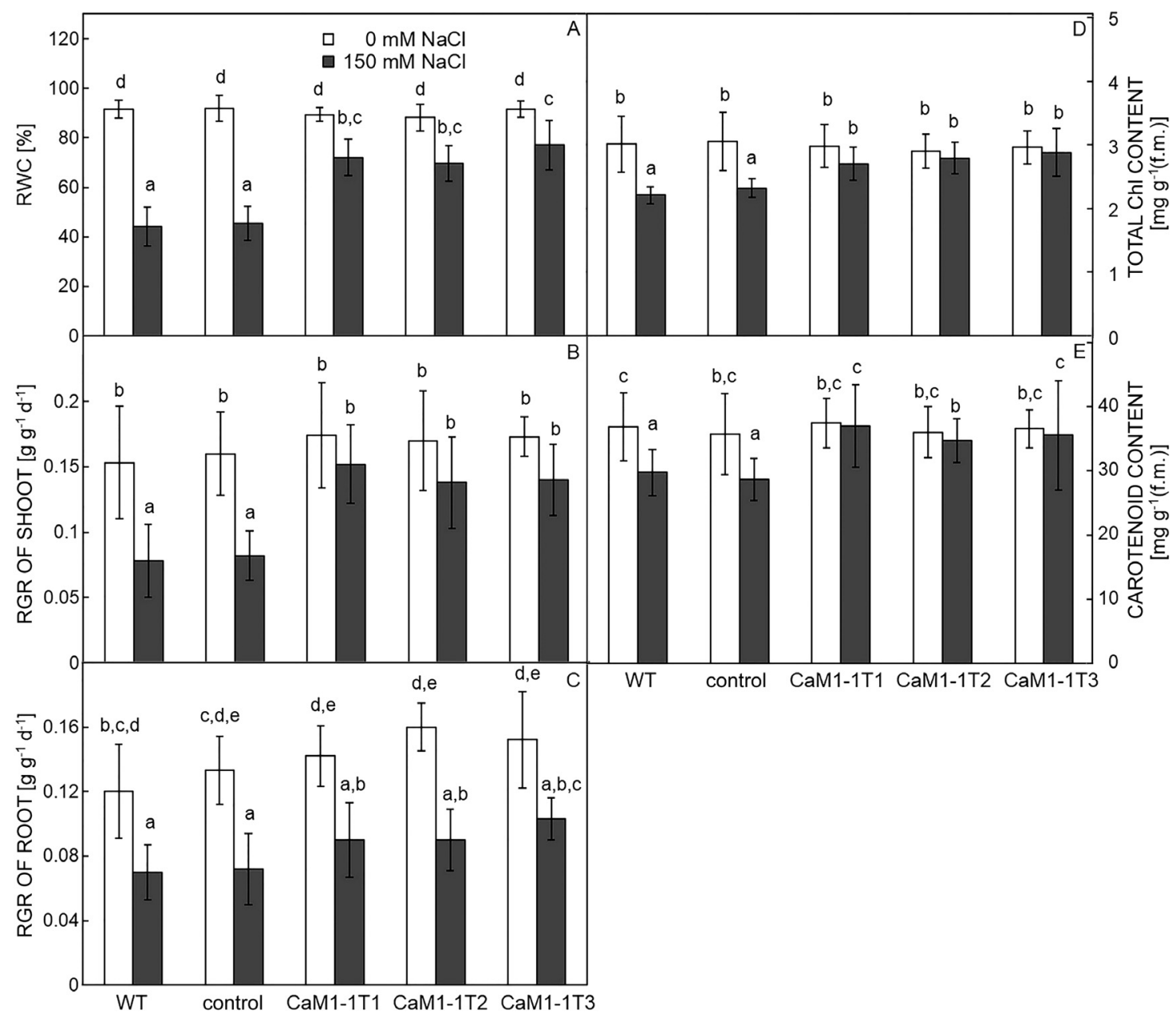

Fig. 2. Effect of $150 \mathrm{mM} \mathrm{NaCl}$ for $3 \mathrm{~d}$ on RWC $(A)$, RGR of shoot $(B)$, RGR of root $(C)$, total chlorophyll content $(D)$, and carotenoid content $(E)$ in the three transgenic plants overexpressing OsCaM1-1 gene (CaM1-1T1, 2, and 3), the negative control transgenic line, and the wild-type. Means \pm SEs, $n=10$ for RGR and 5 for others). Different letters indicate significant differences at $P<0.05$.

significant effect on photosynthetic pigments (total chlorophyll and carotenoids) in the transgenic plants but had a significant negative effect on them in the control and WT (Fig. 2D-E). The decreased content of photosynthetic pigments under salinity may be due to the increasing activity of the chlorophyll-degrading enzyme, chlorophyllase (Reddy and Vora 1986), degradation of $\beta$-carotene, and formation of zeaxanthins, which are apparently involved in protection against photoinhibition (Sharma and Hall 1991). Carotenoids are main antioxidants in plant leaf cells and play an important role against oxidative stress (Verma and Mishra 2005, Gill and Tuteja, 2010). Their content is often increased in the plants under abiotic stresess (Kholová et al. 2011, Peng et al. 2015), but our result showed that their content in the transgenic plants decreased slightly under salinity when compared to the control and WT. These results suggested that the transgenic lines overexpressing OsCaM1-1 could protect the photosynthetic systems from salt-induced injury better than the control and WT.

The DPPH assay is rapid and sensitive way to analyze the antioxidant activity of plant extracts. The salinity stress caused a significant increase in DPPH radical scavenging activity in the transgenic plants, which was 
about 2-fold higher than that of control and WT (Fig. 3A). Various environmental stresses lead to excessive production of ROS such as $\mathrm{H}_{2} \mathrm{O}_{2}$, a product of SOD reaction, a strong oxidant, however, it has an important role in redox signaling (Rhee 2006). ROS can be eliminated by the action of several non-enzymatic and enzymatic processes in cells. In enzymatic processes, excessive content of $\mathrm{H}_{2} \mathrm{O}_{2}$ could be minimized through the activities of CAT and different peroxidases, which help maintain its level and prevent uncontrolled export of this toxic species from organelles to cytosol. While GR, one of the important enzymes in the ascorbate-glutathione cycle, catalyzes the NADPH-dependent reduction of oxidized glutathione and is important in protecting many plants from oxidative stress (Foyer et al. 1991). Induction of antioxidant enzymes is one of the earlier response

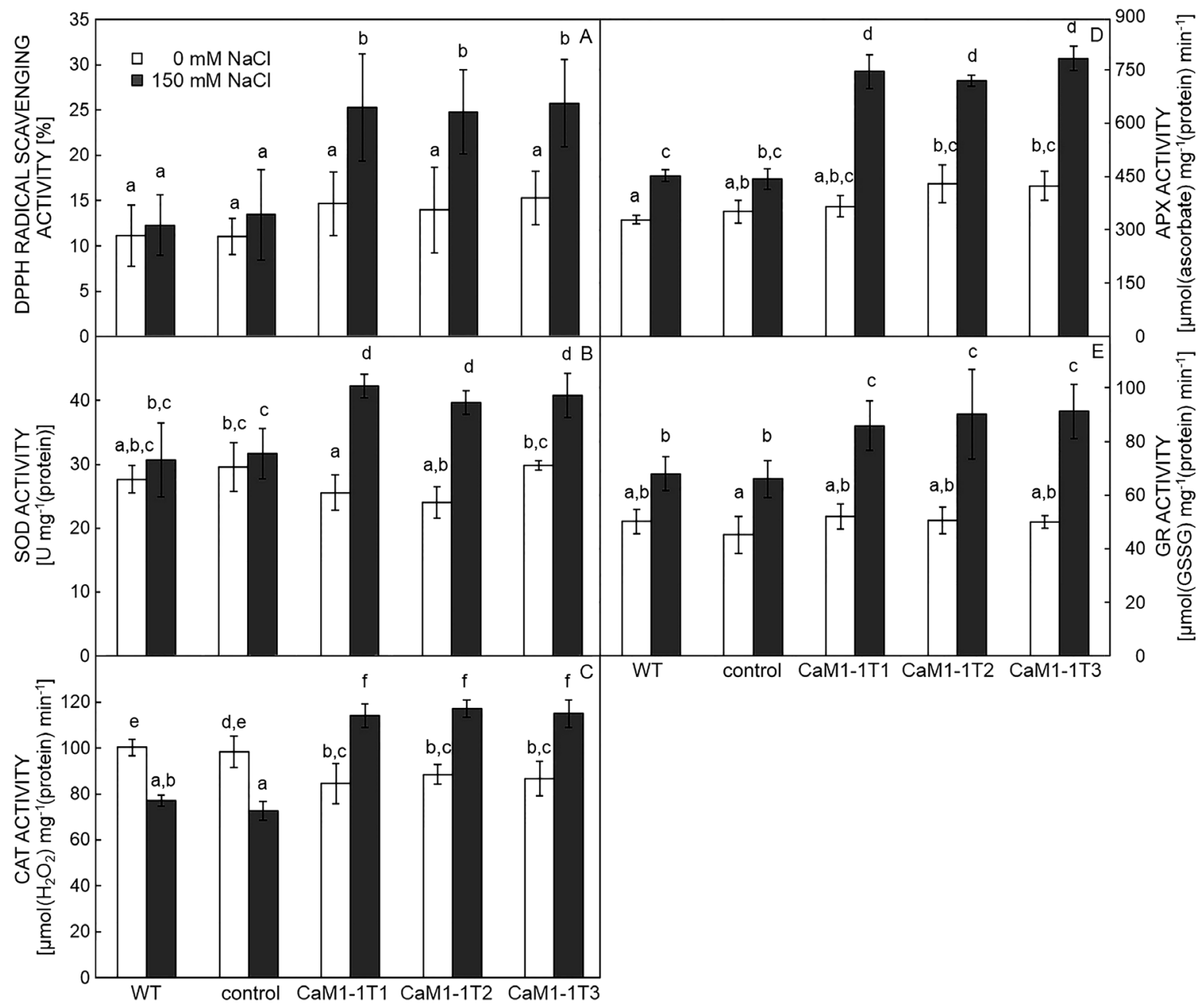

Fig. 3. Effect of $150 \mathrm{mM} \mathrm{NaCl}$ for $3 \mathrm{~d}$ on DPPH radical scavenging activity $(A)$, and SOD $(B)$, CAT $(C)$, APX $(D)$, and GR $(E)$ activities of the transgenic rice plants overexpressing OsCaM1-1 gene (CaM1-1T1, 2, and 3), the negative control transgenic line, and the wild-type. Means \pm SEs, $n=5$. Different letters indicate significant differences at $P<0.05$.

mechanisms against environmental stresses. To determine the response of the transgenic plants to salt-induced oxidative stress, antioxidant enzymes activities in leaves of seedlings grown under salinity were measured in comparison with the control and WT plants. The results showed that salinity caused an increase in SOD, APX, and GR activities (Fig. $3 B, D, E$ ) in all plants, but especially in the transgenic plants. However, salinity led to a significant decrease in CAT activities in the control and WT, whereas in the transgenic plants, a significant increase in CAT activity was observed (Fig. 3C). The increased activities SOD, GR, and APX under salinity are consistent with the previous reports in moderately salinity tolerant wheat genotype and in pea leaves (Hernandez and Alamansa 2002, Sairam et al. 2005), whereas in tobacco salinity has no effect on SOD activity (Hoque et al. 2007). A decreased CAT activity under salinity was observed in the rice cv. Dongjin seedlings, mung bean, tobacco suspension, and rapeseed under salinity (Lee et al. 2001, Hossain et al. 2011, Hoque et al. 2006, Hasanuzzaman et al. 2011), which is similar to our result in the control and WT plants. However, other reports 
showed that salinity results in an increase in the CAT activity, such as in the Lycopersicon pennellii and Plantago maritima (Mittova et al. 2003, Sekmen et al. 2007), which is consistent with our report in the transgenic plants. An increase in $\mathrm{H}_{2} \mathrm{O}_{2}$ generation in the leaves of salt-stressed rice plants may function in the signaling of oxidative stress, which leads to induction of

\section{References}

Ahmad, R.T., Malik, T.A., Khan, I.A., Jaskani, M.J.A.: Genetic analysis of some morpho-physiological traits related to drought stress in cotton (Gossypium hirsutum). - Int. J. Agr. Biol. 11: 235-240, 2009.

Apel, K., Hirt, H.: Reactive oxygen species: metabolism, oxidative stress, and signal transduction. - Annu. Rev. Plant. Biol. 55: 373-399, 2004.

Arnon, D.I.: Copper enzymes in isolated chloroplasts. Polyphenol oxidase in Beta vulgaris. - Plant. Physiol. 24: 1-15, 1949.

Bajji, M., Kinet, J.M., Lutts, S.: The use of the electrolyte leakage method for assessing cell membrane stability as a water stress tolerance test in durum wheat. - Plant Growth Regul. 2001: 1$10,2001$.

Barrs, H.D., Weatherley, P.E.: A re-examination of the relative turgidity technique for estimating water deficit in leaves. Aust. J. biol. Sci. 15: 413-428, 1962.

Beadle, C.L.: Growth analysis. - In: Hall, D.O., Scurlock, J.M.O., Bolhar-Nordenkampf, H.R., Leegood, R.C., Long, S.P. (ed.): Photosynthesis and Production in a Changing Environment. A Field and Laboratory Manual. Pp. 36-46. Chapman \& Hall, London 1993.

Blum, A., Ebercon, A.: Cell membrane stability as a measure of drought and heat tolerance in wheat. - Crop. Sci. 21: 43-47, 1981.

Boonburapong, B., Buabooch, T.: Genome-wide identification and analyses of the rice calmodulin and related potential calcium sensor proteins. - BMC Plant Biol. 7: 1-17, 2007.

Bouche, N., Yellin, A., Snedden, W.A., Fromm, H.: Plantspecific calmodulin-binding proteins. - Annu. Rev. Plant. Biol. 56: 435-466, 2005.

Bradford, M.M.: A rapid and sensitive method for the qualitatively of microgram quantities of protein utilizing the principle of protein-dye binding. - Anal. Biochem. 72: 248254, 1976.

Brand-Williams, W. Cuvelier, M.E. Berset, C.: Use of a free radical method to evaluate antioxidant activity. - Leb. Wiss. Tech. 28: 25-30, 1995.

Campos, P.S., Quartin, V., Ramalho, J.C., Nunes, M.A.: Electrolyte leakage and lipid degradation account for cold sensitivity in leaves of Coffea sp. plants. - Plant. Physiol. 160: 283-292, 2003.

Cao, W.H., Liu, J., He, X.J., Mu, R.L., Zhou, H.L., Chen, S.Y., Zhang, J.S.: Modulation of ethylene responses affects plant salt-stress responses. - Plant. Physiol. 143: 707-719, 2007.

Chaicherdsakul, T., Yuenyong, W., Roytrakul, S., Chadchawan, S., Wutipraditkul, N., Limpaseni, T., Buaboocha, T.: Proteomic analysis of transgenic rice overexpressing a calmodulin calcium sensor reveals its effects on redox signaling and homeostasis. - J. Plant Biochem. Biotechnol. 26: 235-245, 2017.

Chinpongpanich, A., Limruengroj, K., Phean-O-Pas, S., some enzyme activities.

These results suggested that the overexpression of OsCaM1-1 gene may confer the transgenic plants with a more active antioxidative capacity, thus providing protection against ROS under salinity. This is likely through induced cooperation of antioxidants to eliminate excessive ROS under salinity.

Limpaseni, T., Buaboocha, T.: Expression analysis of calmodulin and calmodulin-like genes from rice, Oryza sativa L. - BMC res. Notes 5: 625, 2012.

Davies, K.J.A.: Protein damage and degradation by oxygen radicals: general aspects. - J. biol. Chem. 262: 9895-9901, 1987.

De Vos, C., Schat, H., Vooijs, R., Ernst, W.: Copper induced damage to the permeability barrier in roots of Silene cucubalus - J. Plant. Physiol. 135: 164-165, 1989.

Dionisio-Sese, M.L., Tobita, S.: Antioxidant responses of rice seedlings to salinity stress. - Plant. Sci. 135: 1-9, 1998.

Foyer, C.H., Lelandais, M., Galap, C., Kunert, K.J.: Effects of elevated glutathione reductase activity on the cellular glutathione pool and photosynthesis in leaves under normal and stress conditions. - Plant. Physiol. 97: 863-8m72, 1991.

Fridovich, I.: Superoxide dismutases. -Adv. Enzym. mol. relate Areas mol. Biol. 5: 61-97, 1986.

Gill, S.S., Tuteja, N.: Reactive oxygen species and antioxidant machinery in abiotic stress tolerance in crop plants. - Plant Physiol Biochem. (Paris) 48: 909-930, 2010.

Gueta-Dahan, Y., Yaniv, Z. Zilinskas, B.A., Ben-Hayyim, G.: Salt and oxidative stress: similar and specific responses and their relation to salt tolerance in citrus. - Planta. 203: 460-469, 1997.

Hadi, M.R., Karimi, N.: The role of calcium in plants' salt tolerance. - J. Plant Nutr. 35: 2037-2054, 2012.

Halder, K.P., Burrage, S.W.: Drought stress effects on water relations of rice grown in nutrient film technique. - Pak. J. biol. Sci. 6: 441-444, 2003.

Hasanuzzaman, M., Hossain, M.A., Fujita, M.: Selenium-induced upregulation of the antioxidant defense and methylglyoxal detoxification system reduces salinity-induced damage in rapeseed seedlings. - Biol. Trace Elemen Res. 143: 17041721, 2011.

Hasegawa, P.M., Bressan, R.A., Zhu, J.K., Bohnert, H.J.: Plant cellular and molecular responses to high salinity. - Annu. Rev. Plant. Physiol. Plant. mol. Biol. 51: 463-99, 2000.

Hernandez, J.A., Alamansa, M.S.: Short-term effects of salt stress on antioxidant systems and leaf water relations of pea leaves. - Physiol. Plant. 115: 251-257, 2002.

Hoque, M.A., Banu, M.N.A., Okuma, E., Amako, K., Nakamura, Y., Shimoishi, Y., Murata, Y.: Exogenous proline and glycinebetaine increase $\mathrm{NaCl}$-induced ascorbate-glutathione cycle enzyme activities, and proline improves salt tolerance more than glycinebetaine in tobacco Bright Yellow-2 suspension-cultured cells. - J. Plant. Physiol. 164: 1457-1468, 2007.

Hoque, M.A., Okuma, E., Banu, M.N.A., Nakamura, Y., Shimoishi, Y., Murata, Y.: Exogenous proline mitigates the detrimental effects of salt stress more than exogenous betaine by increasing antioxidant enzyme activities. - J. Plant. 
Physiol. 164: 553-561, 2006.

Hossain, M.A., Hasanuzzaman, M., Fujita, M.: Coordinate induction of antioxidant defense and glyoxalase system by exogenous proline and glycinebetaine is correlated with salt tolerance in mung bean. - Front. Agr. China 5: 1-14, 2011.

Imlay, J.A., Linn, S.: DNA damage and oxygen radical toxicity. Science 240: 1302-1308, 1988.

Jana, S., Choudhuri, M.A.: Glycolate metabolism of three submerged aquatic angiosperms during aging. - Aquat. Bot. 12: 345-354, 1981.

Jin, Z.M., Wang, C.H., Liu, Z.P., Gong, W.J.: Physiological and ecological characters studies on Aloe vera under soil salinity and seawater irrigation. - Process Biochem. 42: 710-714, 2007.

Khan, M.I.R., Asgher, M., Khan, N.A.: Alleviation of saltinduced photosynthesis and growth inhibition by salicylic acid involves glycinebetaine and ethylene in mungbean (Vigna radiata L.). - Plant Physiol Biochem. 80:67-74, 2014.

Khan, M.I.R., Iqbal, N., Masood, A., Khan, N.A.: Variation in salt tolerance of wheat cultivars: role of glycinebetaine and ethylene. - Pedosphere 22: 746-754, 2012.

Kholová, J., Hash, C., Kocova, M., Vadez, V.: Does a terminal drought tolerance QTL contribute to differences in ROS scavenging enzymes and photosynthetic pigments in pearl millet exposed to drought? - Environ. exp. Bot. 71: 99-106, 2011.

Lechno, S., Zamski, E., Tel-Or, E.: Salt stress-induce responses in cucumber plants. - J. Plant. Physiol. 150: 206-211, 1997.

Lee, H.D., Kim, Y.S., Lee, C.B.: The inductive responses of the antioxidant enzymes by salt stress in the rice (Oryza sativa L.). - J. Plant. Physiol. 158: 735-745, 2001.

Li, L., Qu, R., De Kochk, A., Fauquet, C.M., Beachy, R.N.: An improved rice transformation method using the biolistic method. - Plant Cell Rep. 12: 250-255, 1993.

Lopez, C.M.L., Takahashi, H., Yamazaki, S.: Plant-water relations of kidney bean plants treated with $\mathrm{NaCl}$ and foliarly applied glycinebetaine. - J. Agron. Crop. Sci. 188: 73-80, 2002.

Mahajan, S., Tuteja, N.: Cold, salinity and drought stresses: an overview. - Arch. Biochem. Biophys. 444: 139-58, 2005.

Meloni, D.A., Oliva, M.A., Martinez, C.A., Cambraia, J.: Photosynthesis and activity of superoxide dismutase, peroxidase and glutathione reductase in cotton under salt stress. - Environ. exp. Bot. 49: 69-76, 2003.

Mittova, V., Guy, M., Tal, M., Volokita, M.: Salinity up-regulates the antioxidative system in root mitochondria and peroxisomes of the wild salt-tolerant tomato species Lycopersicon pennellii. - J. exp. Bot. 55: 1105-1113, 2004.

Mittova, V., Tal, M., Volokita, M., Guy, M.: Up-regulation of the leaf mitochondrial and peroxisomal antioxidative systems in response to salt-induced oxidative stress in the wild salttolerant tomato species Lycopersicon pennellii. - Plant Cell Environ. 26: 845-856, 2003.

Munns, R., Wallace, P.A., Teakle, N.L., Colmer, T.D.: Measuring soluble ion concentrations $\left(\mathrm{Na}^{+}, \mathrm{K}^{+}, \mathrm{Cl}^{-}\right)$in salt-treated plants. - In: Sunkar, R. (ed.): Methods in Molecular Biology. Pp. 371-382. Humana Press, New York 2010.

Niu, X., Bressan, R., Hasegawa, P., Pardo, J.: Ion homeostasis in $\mathrm{NaCl}$ stress environments. - Plant Physiol. 109: 735-742, 1995.

Peng, Y., Wang, Y., Fei, J., Sun, C., Cheng, H.: Ecophysiological differences between three mangrove seedlings (Kandelia obovata, Aegiceras corniculatum and Avicennia marina) exposed to chilling stress. - Ecotoxicology 24: 1722-1732, 2015.

Per, T.S., Khan, N.A., Reddy, P.S., Asim, M., Hasanuzzaman, M., Khan, M.I.R., Anjum, N.A.: Approaches in modulating proline metabolism in plants for salt and drought stress tolerance: phytohormones, mineral nutrients and transgenics. - Plant Physiol. Biochem. 115: 126-140, 2017.

Pérez-Clemente, R.M., Vives, V., Zandalinas, S.I., LópezCliment, M.F., Muñoz, V., Gómez-Cadenas, A.: Biotechnological approaches to study plant responses to stress. - Biomed. Res. Int. 2013: 1-10, 2012.

Phean-O-Pas, S., Limpaseni, T., Buaboocha, T.: Structure and expression analysis of the OsCam1-1 calmodulin gene from Oryza sativa L. - BMC Rep. 41: 771-777, 2008.

Phean-O-Pas, S., Punteeranurak, P., Buaboocha, T.: Calcium signaling-mediated and differential induction of calmodulin gene expression by stress in Oryza sativa L. - J. Biochem. mol. Biol. 38: 432-439, 2005.

Reddy, M.P., Vora, A.B.: Changes in pigment composition, Hill reaction activity and saccharides metabolism in bajra (Pennisetum typhoides $\mathrm{S} \& \mathrm{H}$ ) leaves under $\mathrm{NaCl}$ salinity. Photosynthetica 20: 50-55, 1986.

Rhee, S.G.: $\mathrm{H}_{2} \mathrm{O}_{2}$, a necessary evil for cell signaling. - Science 312: 1882-1883, 2006.

Saeng-ngam, S., Takpirom, W., Buaboocha, T., Chadchawan, S.: The role of the OsCam 1-1 salt stress sensor in ABA accumulation and salt tolerance in rice. - J. Plant. Biol. 55: 198-208, 2012.

Sairam, R.K., Srivastava, G.C., Agarwal, S., Meena, R.C.: Differences in antioxidant activity in response to salinity stress in tolerant and susceptible wheat genotypes. - Biol. Plant. 49: 85-91, 2005.

Sairam, R.K., Tyagi, A.: Physiology and molecular biology of salinity stress tolerance in plants. - Curr. Sci. 86: 407-421, 2004.

Savouré, A., Thorin, D., Davey, M., Hua, X.J., Mauro, S., Van Montagu, M., Inzé, D., Verbruggen, $\mathrm{N}$.: $\mathrm{NaCl}$ and $\mathrm{CuSO}_{4}$ treatments trigger distinct oxidative defence mechanisms in Nicotiana plumbaginifolia L. - Plant Cell Environ. 22: 387396, 1999.

Sekmen, A.H., Türkan, I., Takio, S.: Differential responses of antioxidative enzymes and lipid peroxidation to salt stress in salt-tolerant Plantago maritima and salt-sensitive Plantago media. - Physiol. Plant. 131: 399-411, 2007.

Sharma, P.K., Hall, D.O.: Interaction of salt stress and photoinhibition on photosynthesis in barley and sorghum. - J. Plant. Physiol. 138: 614-619, 1991.

Valentovič, P., Luxová, M., Kolarovič, L., Gašparíková, O.: Effect of osmotic stress on compatible solutes content, membrane stability and water relations in two maize cultivars. - Plant Soil Environ. 52: 186-191, 2006.

Verma, S., Mishra, S.N.: Putrescine alleviation of growth in salt stressed Brassica juncea by inducing antioxidative defense system. - J. Plant. Physiol. 162: 669-677, 2005.

Wutipraditkul, N., Wongwean, P., Buaboocha, T.: Alleviation of salt-induced oxidative stress in rice seedlings by proline and/or glycinebetaine. - Biol. Plant. 59: 547-553, 2015.

Yang, T., Poovaiah, B.W.: Hydrogen peroxide homeostasis: activation of plant catalase by calcium/calmodulin. - Proc. nat. Acad. Sci. USA 99: 4097-4102, 2002.

Zhu, J.K.: Salt and drought stress signal transduction in plants. Annu. Rev. Plant. Biol. 53: 247-273, 2002. 